\title{
An Analysis of Professional Alienation in Academics
}

\author{
Oktay Çoban, Mehmet Yıldırım* , Çağdaş Caz \\ School of Physical Education and Sport, Yozgat Bozok University, Turkey
}

Copyright@2019 by authors, all rights reserved. Authors agree that this article remains permanently open access under the terms of the Creative Commons Attribution License 4.0 International License

\begin{abstract}
This study aims to measure level of professional alienation among academics working at different departments. The population of the study consists of 850 academics working at different departments of Yozgat Bozok University at Turkey during 2018-2019 academic year. The sample of the study consists of 192 academics working at different departments of Yozgat Bozok University at Turkey during 2018-2019 academic year and voluntarily participated in online survey sent by researchers. Survey was used as a research method in the present study. Participants' demographic features were collected using "personal information form". Academic Alienation Scale developed by [1] is to analyze participants' alienation towards academic teaching as a profession. The obtained data were statistically analyzed using SPSS 18 software program. Frequency analysis, percentage analysis, arithmetic means, $\mathrm{t}$ test, ANOVA analysis and post hoc tests were used for data analysis. The findings suggest that there were significant differences among levels of professional alienation in academics in terms of academic working years, required materials for academic activities and sufficiency of materials $(\mathrm{p}<0.05)$. On the other hand, no significant differences were observed in terms of gender, title, level of communication with colleagues, exposure to mobbing, place of work, participation in social and sports activities and standard working hours $(\mathrm{p}>0.05)$.
\end{abstract}

Keywords Academic, Alienation, University

\section{Introduction}

In today's world, higher education institutions are considered as a qualified human source, and occupy a vital position when it comes to increasing social life quality and global competitiveness in a country [2]. Both public and private universities greatly contribute to national progress, economic development, innovation and transformation [3]. In addition to shaping social transformations, universities are also influenced by these transformations [4-5-6].

Such changes and transformation in a university environment are known to lead to administrative transformation in higher education, different academic hiring processes, different student profiles, technological developments and innovations, and a higher competitiveness in private sector, which also affects universities' academic structure and academic teaching as a profession. Furthermore, rapid globalization constantly increases pressure on academic life, and results in a fast-growing complex academic structure [7].

An academic is defined as an intellectual, distinguished and specialized person who can fulfill multiple different tasks at the same time such as administration, teaching, scientific research and social services in their affiliated universities [8]. Their role is central to the achievement of academic goals in higher education institutions. However, the idea of business management which has recently popularized in the administration of higher education institutions due to changing conditions make it difficult for academics to fulfill their essential roles as they are expected to perform new tasks [9-10-11]. While higher education institutions were considered communities of colleagues, which attached importance to solidarity, respect, academic freedom and collaboration in the past, they are now argued to turn into a new structure in which economic issues and institutional values are prioritized [12]. Nevertheless, it is also argued that above-mentioned changes in academic structures may influence different aspects such as academics' commitment to their university and profession as well as raising awareness about market values and producing related knowledge [13-14-15].

Alienation, which means "the other, stranger" in Latin and is derived from the word "alineus", is used as "psychopath" in different Western languages such as French, Spanish and German [15]. [16], also states that alienation may also refer to estrangement from an object or idea and that it is a phenomenon peculiar to human nature. Alienation is strongly related to an individual's social circle, and may result in negative behaviors such as rivalry, jealousy, disobedience and aggression. US scientists started to study alienation as a sociological concept during the 1960 s, and subsequently developed different methods to measure it.

Self-alienated individuals are often interested in 
financial income and security rather than internal factors, thus finding it difficult to achieve satisfaction in their jobs. Academics working at universities are often neglected in studies on professional alienation. Hence, it can be noted in different studies on educational organizations that samples usually consists of teachers and students at different levels of education. In this respect, it is safe to argue that complex structure of academic institutions is one of the most crucial factors. It bears utmost importance for academic institutions and society to pay attention to levels of alienation among academics because they may play different roles such as researcher, teacher and administrator [17]. In parallel with universities' main functions, according to [5] an academic is mainly expected to perform research, teach and serve the society.

The present study, which aims to identify levels of professional alienation among academics who fulfill different roles as scientists, researchers, teachers and administrators at different departments, will yield important results for not only academics but also universities and society.

\section{Materials and Methods}

In this section, population and sample of the study, data collection tools and statistical methods used for data analysis are described.

\subsection{Population and Sample of the Study}

The population of the study consists of 850 academics working at different departments of Yozgat Bozok University at Turkey during 2018-2019 academic year. The sample of the study consists of 192 academics who work at different departments of Yozgat Bozok University at Turkey during 2018-2019 academic year and voluntarily participated in online survey sent by researchers.

\subsection{Data Collection Tools}

A primary source research, questionnaire was used as a data collection tool in the present study because it is a cost-effective, feasible and suitable method for collecting information from dispersed and large masses within a short time. The questionnaire form is divided into two parts in the present study. While participants' personal and social features were determined using limited items in the first part, a 5-point Likert type scale was used in the second part in order to measure academics' level of professional alienation.

\subsubsection{Academic Alienation Scale}

Academic Alienation Scale, which was developed by [1] in order to measure participants' level of professional alienation was used in the present study. This data collection tool is a scale with five sub-dimensions and 21 items, ranging from 1 (Totally Disagree) to 5 (Totally Agree). The sub-dimensions of the scale are self-alienation, alienation towards scientific research, alienation towards teaching, isolation and weakness, and total reliability of the scale is .86 , while reliability of its sub-dimensions is $.79, .79, .76, .68$, and .67 , respectively. The maximum score of the scale is 21.00 while the maximum score is 105.00 .

In the present study, total reliability coefficient of the scale was calculated as .85 . A reliability coefficient between .70 and .90 can be considered as a high level of reliability (Bagozzi and Yi, 1988; 76-94, Nunnally and Bernstein, 1994). Therefore, it is evident that the scale meets the minimum requirement for internal reliability coefficients.

\subsection{Data Analysis}

The data obtained from the study was analyzed using SPSS 18.0 package program. Prior to the statistical data analysis, the data must be prepared for analysis because skewness and kurtosis coefficients are of vital importance [16]. A skewness coefficient of (+-2) and a kurtosis coefficient of (+-7) indicate a normal data distribution. [18-19-16]. In the present study, skewness and kurtosis coefficients were calculated as $0.030 / 1.861$ and $0.062 /-2.437$, respectively, thus demonstrating a normal data distribution. Parametric tests were used for statistical analysis.

Frequency analysis was used in order to identify participants' demographic features. $T$ test was used in order to identify differences among levels of academic alienation based on different demographic variables. Finally, ANOVA test and multiple comparison tests (Post-Hoc LSD and Tamhane T2) were used depending on variance homogeneity. Statistical significance level was taken as 0.05 .

\section{Findings}

The findings related to participants' demographic features are given in Table 1.

According to Table 1, 119 participants $(62.0 \%)$ were male while 73 of them $(38.0 \%)$ were female. 9 participants (\%4.6) were professors, 14 of them $(7.2 \%)$ were associated professors, 57 of them were $(29.6 \%)$ assistant professors, 63 of them $(32.8 \%)$ were $\mathrm{PhD}$ lecturers, and 49 of them $(25.5 \%)$ were research assistants. 148 participants $(77.0 \%)$ had $1-10$ years of experience, 33 of them (17.1\%) had 11-20 years of experience, 11 of them $(5.7 \%)$ had 21 years of experience and more. When it comes to level of communication with colleagues, 122 participants $(63.5 \%)$ had a high level of communication, while 63 of them (32.8\%) had a moderate and 7 of them 
(3.6\%) had a poor level of communication. As for exposure to mobbing, 45 participants $(23.4 \%)$ responded 'yes', whereas 57 of them (29.6\%) said 'partly' and 90 of them (46.8\%) said 'no'. 57 of them found $(29.6 \%)$ materials sufficient for academic activities while 67 of them $(34.8 \%)$ said they were partly sufficient and 68 of them $(35.4 \%)$ found them insufficient. While 144 participants' $(75.0 \%)$ place of work and residence are the same, $48 \%$ of them work and live in different places
$(25.0 \%)$. While 45 participants $(23.4 \%)$ participated in social and sports activities in their place of work (province or town), 75 of them (39.0\%) partly participated in these activities, and 72 of them (37.5\%) did not participate at all. As for standard working hours, 69 participants $(35.9 \%)$ answered 'yes', while 57 of them (29.6\%) said 'no' and 66 of them (34.3\%) said 'partly'.

$t$ test findings related to the comparison of mean total scores in terms of gender are given in Table 2.

Table 1. Participants' Demographic Features

\begin{tabular}{|c|c|c|c|}
\hline & & $\mathbf{N}$ & $\%$ \\
\hline \multirow{2}{*}{ Gender } & Male & 119 & 62.0 \\
\hline & Female & 73 & 38.0 \\
\hline \multirow{5}{*}{ Title } & Prof. Dr. & 9 & 4.6 \\
\hline & Assoc. Prof. & 14 & 7.2 \\
\hline & Asst. Prof. & 57 & 29.6 \\
\hline & $\mathrm{PhD}$ & 63 & 32.8 \\
\hline & Research Asst./PhD Research Asst. & 49 & 25.5 \\
\hline \multirow{3}{*}{ Length of Professional Experience } & $1-10$ years & 148 & 77.0 \\
\hline & $11-20$ years & 33 & 17.1 \\
\hline & 21 and more & 11 & 5.7 \\
\hline \multirow{3}{*}{ Level of Communication with Colleagues } & High & 122 & 63.5 \\
\hline & Moderate & 63 & 32.8 \\
\hline & Poor & 7 & 3.6 \\
\hline \multirow{3}{*}{ Exposure to Mobbing } & Yes & 45 & 23.4 \\
\hline & Partly & 57 & 29.6 \\
\hline & No & 90 & 46.8 \\
\hline \multirow{3}{*}{ Sufficiency of Materials for Academic Activities } & Yes & 57 & 29.6 \\
\hline & Partly & 67 & 34.8 \\
\hline & No & 68 & 35.4 \\
\hline \multirow{2}{*}{ Place of Work (Province-Town) and Place of Residence (Province-Town) } & I work and live in the same place & 144 & 75.0 \\
\hline & I work and live in different places & 48 & 25.0 \\
\hline \multirow{3}{*}{ Participation in Social and Sports Activities } & Yes & 45 & 23.4 \\
\hline & Partly & 72 & 37.5 \\
\hline & No & 75 & 39.0 \\
\hline \multirow{3}{*}{ Standard Working Hours } & Yes & 69 & 35.9 \\
\hline & Partly & 57 & 29.6 \\
\hline & No & 66 & 34.3 \\
\hline
\end{tabular}

Table 2. $\mathrm{t}$ test findings related to the comparison of mean total scores in terms of gender

\begin{tabular}{ccccccc}
\hline & Gender & N & Mean & Sd & t & p \\
\hline $\begin{array}{c}\text { Academic Alienation Scale } \\
\text { Mean Total Scores }\end{array}$ & Male & 119 & 2.5 & .31 & \multirow{2}{*}{-.516} & .607 \\
\cline { 2 - 6 } & Female & 73 & 2.97 & .28 & & \\
\hline
\end{tabular}


It can be understood from Table 2 that no statistically significant differences were observed among mean total scores in terms of gender $(\mathrm{p}>.05)$.

ANOVA findings related to the comparison of mean total scores in terms of academic title are given in Table 3.

Table 3. ANOVA findings related to the comparison of mean total scores in terms of academic title

\begin{tabular}{|c|c|c|c|c|c|c|c|c|c|c|}
\hline & Group & $\mathbf{N}$ & $\bar{x}$ & sd & $\begin{array}{l}\text { Source } \\
\text { of Var. }\end{array}$ & $\begin{array}{c}\text { Sum } \\
\text { of Sq. }\end{array}$ & Df. & $\begin{array}{l}\text { M. } \\
\text { Sq. }\end{array}$ & $\mathbf{F}$ & $\mathbf{p}$ \\
\hline \multirow{5}{*}{$\begin{array}{c}\text { Academic Alienation } \\
\text { Scale } \\
\text { Mean Total } \\
\text { Scores }\end{array}$} & Prof. Dr. & 9 & 3.00 & .22 & $\begin{array}{c}\text { Between } \\
\text { Groups }\end{array}$ & 0.638 & 4 & .159 & \multirow{3}{*}{1.811} & \multirow{3}{*}{.128} \\
\hline & Assoc. Prof. & 14 & 3.00 & .30 & Within Groups & 16.456 & 187 & .088 & & \\
\hline & Asst. Prof. & 57 & 2.98 & .30 & Total & 17.094 & 191 & & & \\
\hline & $\mathrm{PhD}$. & 63 & 2.88 & .30 & & & & & & \\
\hline & $\begin{array}{c}\text { Research } \\
\text { Asst. }\end{array}$ & 49 & 3.01 & .29 & & & & & & \\
\hline
\end{tabular}

${ }^{*} \mathrm{p}<.05,{ }^{* *} \mathrm{p}<.01$

Table 3 indicates that there were no statistically significant differences among mean total scores in terms of academic title $(\mathrm{p}>.05)$.

ANOVA findings related to the comparison of mean total scores in terms of professional experience are given in Table 4 .

Table 4. ANOVA findings related to the comparison of mean total scores in terms of professional experience

\begin{tabular}{|c|c|c|c|c|c|c|c|c|c|c|c|}
\hline & Group & $\mathbf{N}$ & $\bar{x}$ & sd & $\begin{array}{c}\text { Source of } \\
\text { Var. }\end{array}$ & $\begin{array}{c}\text { Sum of } \\
\text { Sq. }\end{array}$ & Df. & $\begin{array}{l}\text { M. } \\
\text { Sq. }\end{array}$ & F & $\mathbf{p}$ & $\begin{array}{l}\text { Significant } \\
\text { Difference }\end{array}$ \\
\hline \multirow{3}{*}{$\begin{array}{c}\text { Academic } \\
\text { Alienation Scale } \\
\text { Mean Total } \\
\text { Scores }\end{array}$} & $1-10$ yr. (1) & 148 & 2.93 & .29 & $\begin{array}{c}\text { Between } \\
\text { Groups }\end{array}$ & .805 & 2 & .403 & \multirow{3}{*}{4.670} & \multirow{3}{*}{$.010^{* *}$} & \multirow{3}{*}{$2-1$} \\
\hline & $11-20 y r .(2)$ & 33 & 3.10 & .29 & $\begin{array}{l}\text { Within } \\
\text { Groups }\end{array}$ & 16.289 & 189 & .086 & & & \\
\hline & $\begin{array}{l}21 \text { and } \\
\text { more(3) }\end{array}$ & 11 & 2.93 & .32 & Total & 17.094 & 191 & & & & \\
\hline
\end{tabular}

${ }^{*} \mathrm{p}<.05,{ }^{* *} \mathrm{p}<.01$

It can be seen in Table 4 that a statistically significant difference was found among mean total scores in terms of professional experience $(F=4.670 ; p=.010)$. It was observed that academics with a professional experience of 11-20 years had a higher level of academic alienation compared to those with a professional experience of 1-10 years.

ANOVA findings related to the comparison of mean total scores in terms of level of communication with colleagues are given in Table 5 .

Table 5. ANOVA findings related to the comparison of mean total scores in terms of level of communication with colleagues

\begin{tabular}{|c|c|c|c|c|c|c|c|c|c|c|}
\hline & Group & $\mathbf{N}$ & $\bar{x}$ & sd & Source of Var. & Sum of Sq. & df & M. Sq. & $\mathbf{F}$ & p \\
\hline \multirow{3}{*}{$\begin{array}{c}\text { Academic Alienation Scale } \\
\text { Mean Total } \\
\text { Scores }\end{array}$} & High & 122 & 2.93 & .29 & Between Groups & .224 & 2 & .112 & \multirow{3}{*}{1.258} & \multirow{3}{*}{.287} \\
\hline & Moderate & 63 & 2.98 & .31 & Within Groups & 16.870 & 189 & .089 & & \\
\hline & Poor & 7 & 3.08 & .20 & Total & 17.094 & 191 & & & \\
\hline
\end{tabular}

${ }^{*} \mathrm{p}<.05,{ }^{* *} \mathrm{p}<.01$

It can be inferred from Table 5 that no statistically significant differences were found among mean total scores in terms of communication with colleagues $(\mathrm{p}>.05)$.

ANOVA findings related to the comparison of mean total scores in terms of exposure to mobbing are given in Table 6.

Table 6. ANOVA findings related to the comparison of mean total scores in terms of exposure to mobbing

\begin{tabular}{|c|c|c|c|c|c|c|c|c|c|c|}
\hline & Group & $\mathbf{N}$ & $\bar{x}$ & sd & Source of Var. & Sum of Sq. & Df. & M. Sq. & $\mathbf{F}$ & $\mathbf{p}$ \\
\hline \multirow{3}{*}{$\begin{array}{c}\text { Academic Alienation Scale } \\
\text { Mean Total } \\
\text { Scores }\end{array}$} & Yes & 45 & 3.02 & .30 & Between Groups & .256 & 2 & .128 & \multirow{3}{*}{1.438} & \multirow{3}{*}{.240} \\
\hline & Partly & 57 & 2.92 & .28 & Within Groups & 16.838 & 189 & .089 & & \\
\hline & No & 90 & 2.95 & .29 & Total & 17.094 & 191 & & & \\
\hline
\end{tabular}

${ }^{*} \mathrm{p}<.05,{ }^{* *} \mathrm{p}<.01$

Table 6 indicates that no statistically significant differences were observed among mean total scores in terms of 
exposure to mobbing $(\mathrm{p}>.05)$.

ANOVA findings related to the comparison of mean total scores in terms of sufficiency of materials for academic activities are given in Table 7.

Table 7. ANOVA findings related to the comparison of mean total scores in terms of sufficiency of materials for academic activities

\begin{tabular}{|c|c|c|c|c|c|c|c|c|c|c|c|}
\hline & Group & $\mathbf{N}$ & $\bar{x}$ & sd & $\begin{array}{c}\text { Source of } \\
\text { Var. }\end{array}$ & $\begin{array}{c}\text { Sum of } \\
\text { Sq. }\end{array}$ & df & $\begin{array}{l}\text { M. } \\
\text { Sq. }\end{array}$ & $\mathbf{F}$ & $\mathbf{p}$ & $\begin{array}{l}\text { Significant } \\
\text { Differences }\end{array}$ \\
\hline \multirow{3}{*}{$\begin{array}{c}\text { Academic } \\
\text { Alienation Scale } \\
\text { Mean Total } \\
\text { Scores }\end{array}$} & Yes (1) & 57 & 2.93 & .33 & $\begin{array}{l}\text { Between } \\
\text { Groups }\end{array}$ & .859 & 2 & .429 & \multirow{3}{*}{4.998} & \multirow{3}{*}{$.008^{* *}$} & \multirow{3}{*}{$3-1 / 2$} \\
\hline & $\begin{array}{l}\text { Partly } \\
\text { (2) }\end{array}$ & 67 & 2.89 & .23 & $\begin{array}{l}\text { Within } \\
\text { Groups }\end{array}$ & 16.236 & 189 & .086 & & & \\
\hline & No (3) & 68 & 3.04 & .30 & Total & 17.094 & 191 & & & & \\
\hline
\end{tabular}

${ }^{*} \mathrm{p}<.05,{ }^{* *} \mathrm{p}<.01$

According to Table 7, a statistically significant difference was observed among mean total scores in terms of sufficiency of materials for academic activities $(F=4.998 ; p=.008)$. It was found out that academics who answered 'no' had a higher level of alienation compared to those who answered 'yes' and 'partly'.

$t$ test findings related to the comparison of mean total scores in terms of place of work (province/town) and residence (province/town) are given in Table 8.

Table 8. $t$ test findings related to the comparison of mean total scores in terms of place of work (province/town) and residence (province/town)

\begin{tabular}{|c|c|c|c|c|c|c|}
\hline & Place of work (province/town) and Residence (province/town) & $\mathbf{N}$ & Mean & Sd & $\mathbf{t}$ & $\mathbf{p}$ \\
\hline \multirow{2}{*}{$\begin{array}{c}\text { Academic Alienation Scale } \\
\text { Mean Total } \\
\text { Scores }\end{array}$} & I work and live in the same place & 144 & 2.96 & .30 & \multirow[b]{2}{*}{.265} & \multirow[b]{2}{*}{.792} \\
\hline & I work and live in different places & 48 & 2.95 & .26 & & \\
\hline
\end{tabular}

Table 8 demonstrates that no statistically significant differences were found among mean total scores in terms of place of work (province/town) and residence (province/town) ( $>$ >.05).

ANOVA findings related to the comparison of mean total scores in terms of participation in social and sports activities in place of residence (province/town) are given in Table 9.

Table 9. ANOVA findings related to the comparison of mean total scores in terms of participation in social and sports activities in place of residence (province/town)

\begin{tabular}{|c|c|c|c|c|c|c|c|c|c|c|}
\hline & Group & $\mathbf{N}$ & $\bar{x}$ & sd & Source of Var. & Sum of Sq. & df & M. Sq. & $\mathbf{F}$ & $\mathbf{p}$ \\
\hline \multirow{3}{*}{$\begin{array}{c}\text { Academic Alienation Scale } \\
\text { Mean Total } \\
\text { Scores }\end{array}$} & Yes & 45 & 2.96 & .34 & Between Groups & .199 & 2 & .100 & \multirow{3}{*}{1.115} & \multirow{3}{*}{.330} \\
\hline & Partly & 72 & 2.99 & .29 & Within Groups & 16.895 & 189 & .089 & & \\
\hline & No & 75 & 2.92 & .27 & Total & 17.094 & 191 & & & \\
\hline
\end{tabular}

${ }^{*} \mathrm{p}<.05,{ }^{* *} \mathrm{p}<.01$

It can be understood from Table 9 that no statistically significant differences were observed among mean total scores in terms of participation in social and sports activities in place of residence (province/town) ( $>$ >.05).

ANOVA findings related to the comparison of mean total scores in terms of standard working hours in the academic institution are given in Table 10.

Table 10. ANOVA findings related to the comparison of mean total scores in terms of standard working hours in the academic institution

\begin{tabular}{|c|c|c|c|c|c|c|c|c|c|c|}
\hline & Group & $\mathbf{N}$ & $\bar{x}$ & sd & Source of Var. & Sum of Sq. & df & M. Sq. & $\mathbf{F}$ & $\mathbf{p}$ \\
\hline \multirow{3}{*}{$\begin{array}{c}\text { Academic Alienation Scale } \\
\text { Mean Total } \\
\text { Scores }\end{array}$} & Yes & 69 & 2.94 & .28 & Between Groups & .051 & 2 & .025 & \multirow{3}{*}{.281} & \multirow{3}{*}{.755} \\
\hline & Partly & 57 & 2.95 & .35 & Within Groups & 17.044 & 189 & .090 & & \\
\hline & No & 66 & 2.98 & .25 & Total & 17.094 & 191 & & & \\
\hline
\end{tabular}

" $<<.05$, , $\mathrm{p}<.01$

It is evident in Table 10 that no statistically significant differences were found among mean total scores in terms of standard working hours $(\mathrm{p}>.05)$.

Any comments and suggestions are welcomed so that we can constantly improve this template to satisfy all authors' research needs. 


\section{Discussion}

In this section, the obtained data are compared with similar studies in the literature. No statistically significant differences were observed among mean total academic alienation scale scores in terms of gender. [20] reported no significant differences between males and females in terms of professional alienation in a study on $\mathrm{PhD}$ lecturers. In a study on classroom teachers, [21] found no significant differences between male and female teachers in terms of professional alienation. Similarly, [22] did not find out any significant differences between male and female teachers in public and private high schools. [23] also did not observe any differences between male and female physical education teachers. In a similar vein, [24] analyzed teachers' level of school alienation and concluded that there were no differences between female and male teachers. [25] did not find any significant differences between female and male nurses in terms of work alienation. Finally, [26] also did not find any significant differences between female and male teachers in terms of work alienation.

In the present study, no statistically significant differences were observed among mean total scores in terms of academic title. On the other hand, [20] reported some significant differences among academics with different titles when it comes to professional alienation.

In terms of academics' length of experience, a statistically significant difference was identified among mean total scores as academics who had an experience of 11-20 years had a higher level of academic alienation compared to those who had an experience of 1-10 years. However, some studies in the existing literature do not overlap this finding. For instance, according to [21] professional alienation did not lead to a significant difference among classroom teachers with different lengths of experience. [22] did not find any significant differences among public and private high school teachers with different lengths of experience in terms of organizational alienation. [27] similarly, did not report any significant differences among levels of professional alienation in teachers with difference lengths of experiences. [23] also did not identify any significant differences among physical education teachers with different lengths of experience. [24] in a study on different teachers, found out that length of experience did not lead to any significant differences in terms of school alienation. [25] stated that no significant differences were observed among nurses with different lengths of experience as far as work alienation is concerned. [26] revealed that there were no significant differences among teachers with different lengths of experience in terms of professional alienation.

\section{Conclusions}

In the present study, no statistically significant differences were found among levels of academic alienation in terms of gender. It can be inferred from this finding that female and male academics' levels of academic alienation are similar. In addition,' level of academic alienation did not create any statistically significant differences in terms of academic title, indicating that different titles did not influence professional alienation.

Academics' length of experience did not lead to any significant differences for academic alienation. The length of academic experience is directly proportional to academic alienation. However, no significant differences were found among levels of academic alienation in terms of communication with colleagues. Similarly, there were no significant differences between academics when it comes to exposure to mobbing.

As for sufficiency of materials for academic activities, a statistically significant difference was observed among academics' levels of alienation. It was found out that academics who answered 'yes' had a higher level of academic alienation when compared to those who answered 'yes' and 'partly'. Research plays a vital role for academic activities. Therefore, it can be argued that academics' level of professional alienation is negatively influenced when their academic activities are hindered.

As for academics' place of work (province/town) and residence (province/ town), no statistically significant differences were observed among levels of academic alienation. Similarly, there were no statistically significant differences among levels of academic alienation in terms of participation in social and sports activities in academics' place and residence of work.

Finally, no statistically significant differences were found among scores of academic alienation in terms of standard working hours in academics' respective institution.

\section{REFERENCES}

[1] Yıldız, S. ve Alıc1, D. (2019). Akademisyenliğe yabanc>laflma ölçeğinin gelifltirilmesi: Geçerlik ve güvenirlik çalışlması. Yükseköğretim Dergisi, doi:10.2399/yod.18.028.

[2] Acar, M., Bilir, H. (2013). Serbest piyasa, yeniden rekabet: sitelerde piyasa yönelimli yeniden yapılanma ihtiyac1. Yükseköğretim ve Bilim Dergisi, 8(8), 184-192.

[3] Bingöl, B. (2012). Üniversite özerkliğinin değişen tanımı ve üniversitelerin yeniden yapılandırılması. Hacettepe Hukuk Fakültesi Dergisi, 2(2), 39-75.

[4] Erdem, A. R. (2006). Dünyadaki yükseköğretimin değişimi. Selçuk Üniversitesi Sosyal Bilimler Enstitüsü Dergisi, 15, 299- 314.

[5] Günay, D. (2011). Türk yükseköğretiminin yeniden yapılandırılması bağlamında sorunlar, eğilimler, ilkeler ve 
öneriler-I. Yükseköğretim ve Bilim Dergisi, 1(3), 113-121.

[6] Marginson, S. (2000). Rethink academic work in the global era. Journal of higher education policy and management, 22(1), 23-35.

[7] Husu, L. (2001). On metaphors on the position of women in academia and science. Taylor \& Fracis, 3(9), 172-182.

[8] Churchman, D. (2006). Institutional commitment, individual compromises: Identity-related responses to compromise in an Australian University. Journal of Higher Education Policy and Management, 28(1), 3-15.

[9] Ünal, B. ve Gizir, S. (2014). Öğretim Elemanlarının Baskın Kariyer Çapalarının İncelenmesi: Mersin Üniversitesi Örneği. Kuram ve Uygulamada Eğitim Bilimleri, 14(5), 1743-1765.

[10] Billiot, J. (2010). The imaginated and the real: Identifying the tensions for academic identity. Higher Education Research \& Development, 29(6), 709-721.

[11] Sakınç, S. ve Bursalığlu, S. A. (2012). Yükseköğretimde küresel bir değişim: girişimci üniversite. Yükseköğretim ve Bilim Dergisi, 2(2), 92-99.

[12] Henkel, M. (2000). Academic identities and policy change in higher education. London: Jessica Kingsley.

[13] Osmanoğlu, Ö. (2008). Yabancılaşma üzerine. Sosyoloji Notları Dergisi, 13-20.

[14] Şimşek, O.F. (2007). Yapısal eşitlik modellemesine giriş, temel ilkeler ve lisrel uygulamaları. Ankara: Ekinoks Yayınları.

[15] Y1ldız, S. (2014). Öğretim üyelerinin üniversite, akademisyenlik mesleği, bilimsel araştırma, öğretim ve öğrenci kavramlarına ilişkin algılarının metaforlar aracılığıyla incelenmesi, Yayınlanmamış Yüksek Lisans Tezi, Mersin Üniversitesi Eğitim Bilimleri Enstitüsü, Mersin.

[16] West, S. G., Finch, J. F., Curran, P. J. (1995). Structural Equation Models With Nonnormal Variables And Remedies. Akt: Hoyle, R.H. (Ed.) (1995). Structural Equation Modeling: Concepts, Issues And Applications, Sage: London.

[17] Şencan, H. (2005). Sosyal ve davranışsal ölçümlerde güvenilirlik ve geçerlik. Ankara: Seçkin Yayınları.

[18] Çivilidağ, A. (2015). Öğretim elemanlarında örgütsel sinizm ve işe yabancılassma arasındaki ilişkide yaşam doyumunun arac1 rolü. "İş, Güç” Endüstri İlişkileri Ve İnsan Kaynakları Dergisi. 17(1), 259-286.

[19] Şimșek, H., Balay, R., Șimșek, A.S. (2012). İlköğretim Sınıf Öğretmenlerinde Mesleki Yabancılaşma. Journal Of Education Sciences Research, 2(1), 53-72.

[20] Ery1lmaz, A., Burgaz, B. (2011). Özel Ve Resmi Lise Öğretmenlerinin Örgütsel Yabancılaşma Düzeyleri. Eğitim ve Bilim. 36(161), 271-286.

[21] Şirin, E.F. (2010). Beden Eğitimi Öğretmenlerinin İșe Yabancılaşma Düzeylerinin Bazı Değişkenler Açısından İncelenmesi. Celal Bayar Üniversitesi, Beden Eğitimi Ve Spor Bilimleri Dergisi. 4(4): 164-177.
[22] Korkmaz, H. (2014). Ortaöğretim devlet okullarında görev yapan öğretmenlerin yabancılaşma düzeyleri ile örgütsel bağlılıkları arasındaki ilişkinin incelenmesi. Yüksek Lisans Tezi, Bahçeşehir Üniversitesi.

[23] Yetiş, Z. (2013). Kamu hastanelerinde çalışan hemşirelerde işe yabancılaşma. Yayımlanmamış Yüksek Lisans Tezi. Atatürk Üniversitesi, Sağlık Bilimleri Enstitüsü.

[24] Abasl1, K. (2018). Örgütsel dişlanma, işe yabancılaşma ve örgütsel sinizm ilişkisine yönelik öğretmen görüşleri. Yayımlanmamış Doktora Tezi. Hacettepe Üniversitesi, Eğitim Bilimleri Enstitüsü.

[25] Kesik, F., Cömert, M. (2014). İlköğretim Okullarında Görev Yapan Öğretmenlerin İşe Yabancılaşma Düzeylerine İlişkin Algıları. İnönü Üniversitesi Eğitim Fakültesi Dergisi. 15(1), 27-46. 